\author{
VERLUMUN CELESTINE GEVER, \\ University of Nigeria (Nsukka, Enugu State, Nigeria) \\ e-mail: Encyclopeadia100@gmail.com,ORCID 0000-0003-0618-5352
}

GABRIEL ALHASSAN OTTAH,

Kogi State University (Anyigba, Nigeria)

ORCID 0000-0002-8958-9258

\title{
INFORMATIONAL DIMENSION OF HIV/AIDS PROBLEM INSIDE INTERNALLY DISPLACED PERSONS COMMUNITY OF NIGERIA
}

This study examined information seeking behaviour of Internally Displaced Persons (IDPs) in Benue State with a view to understanding how to best communicate HIVIAIDS services to them as well as promote policies that could help combat child poverty. A total of 384 IDPs were sampled from four IDP centres in Benue State. The indices that were measured in this study included sources of information, motivation for information seeking, information seeking behaviour, attention to source credibility and knowledge of HIVIAIDs. To measure sources of information, the respondents were requested to provide the sources through which they receive information and also indicate the motivation for doing so. The information seeking behaviour of the respondents was accessed using by classifying the information seeking behaviour of the sample into low information seeking behaviour and high information seeking behaviour. The indices for high and low information seeking behaviour were presented to the respondents who indicated their information seeking behaviour. Attention to source credibility was measured using a dichotomous response format of 'yes' and 'no' which was used to assess source credibility. The two dimensions of that were used are trustworthiness and expertise. Therefore, the researchers asked the respondents to ascertain if they pay attention to source trustworthiness and expertise in their information seeking behaviour. Concerning the knowledge of HIVIAIDS status, the respondents were asked to report if they were aware of their HIVIAIDs status or not. They were asked to indicate their actual status because of the sensitivity of the matter. In the analysis of data for this study, the researcher used both descriptive and inferential statistics. Among the descriptive statistics, simple percentages were used while among the inferential statistics, chi-square test of independence was used. The hypotheses were tested at $\mathbf{0 . 0 5}$ level of significance. The result showed that most of the IDPs get information from family and friends. Information seeking behaviour was found to have significantly associated with sources of information and motivation for seeking information. Also, perceived HIV/Aids information need was associated with information seeking behaviour. HIV/Aids status was also associated with information seeking behaviour. Finally, significant relationship exists between information seeking behaviour of consciousness of source credibility. The implications of these results on HIVI AIDs communication policies are also explored.

Keywords: Communication; information seeking; HIVIAIDs and IDPs.

\section{Introduction}

Information seeking behaviour is one of the attractive areas in communication research. This is because results from such studies could be useful for designing and implementing behaviour change communication. Information seeking behaviour describes deliberate efforts which an individual makes to get information with a view to meeting defined aims. Wilson (2000) says that information seeking behaviour is the purposive seeking for information as a consequence of a need to satisfy some goals. Wilson, adds that in the process of seeking, the individual may interact with manual information systems (such as a newspaper, magazine, TV and radio), or with computerbased systems (such as the new media). The simple implication from the explanation of Wilson is that information seeking behaviour closely tied to communication channel because there cannot be information without communication channel. There must be channel that will disseminate information. Julien, (1996) says that information seeking behaviour can broadly be defined as that which is concerned with determining user's information needs, searching behaviour and subsequent use of information. Knowledge of information seeking behaviour of people is essential for health communication, especially HIVIAIDS. Such research findings could offer greater insights on how to communicate life-saving information to the general public.

HIV and AIDs are serious public health challenges facing the world today. Although different countries of the world have varying degrees of prevalence of the disease, it remains a global threat. There were approximately 36.7 million people living with HIVIAIDS at the end of 2016. Of these, 2.1 million were children ( $<15$ years old). An estimated 1.8 million individuals worldwide became newly infected with HIV in 2016 - about 5,000 new infections per day. Most of these children live in sub-Saharan Africa and 
were infected by their HIV-positive mothers during pregnancy, childbirth or breastfeeding (United Nations Programme on HIVIAIDS UNAIDS, 2017). Nigeria has the second largest HIV epidemic in the world (National Agency for the control of AIDs, NACA 2017). It is estimated that almost two thirds of HIV infections in West and Central Africa in 2016 occurred in Nigeria. Together with South Africa and Uganda, Nigeria accounts for almost half of all new HIV infections in sub-Saharan Africa every year (UNAIDS, 2017). Six states in Nigeria account for $41 \%$ of people living with HIV, including Kaduna, Akwa Ibom, Benue, Lagos, Oyo, and Kano (National Agency for the Control of AIDs, 2017). The situation in Benue State is particularly complex because of increasing cases of internally displaced person. It is argued that strong relationship exists between HIVIAIDs and poverty. When people are infected with the disease, finances that should have been used for properly upbringing of the child are used for health issues. Although management of HIV/AIDs is free, victims may be unable to perform optimally, thus making them less productive. Such parents may also be required to take some diets that may require money. In the event of death, the children also suffer.

Benue State also has many Internally Displaced Persons (IDPs) as a result of the conflict between farmers and herdsmen. United Nations Commission on Human Rights (1992) in its analytical report on IDPs says that IDPs are persons or groups who have been forced to flee their homes suddenly or unexpectedly in large numbers, as a result of armed conflict, internal strife, systematic violations of human rights or natural or man-made disaster, and who are within the territory of their own country. However, $1 \mathrm{n} 1998$, the commission formally recognized the definition of IDPS as people or groups of people who have been compelled or obliged to flee or to leave their homes or places of habitual residence, in particular because of or for the purpose of avoiding the effects of armed conflict, situations of generalized violence, violations of human rights or natural or human-made disasters, and who have not crossed an internationally recognized State border.

There is an increase in cases of IDPS globally. According the Global Statistics on IDPS (2018) as reported by Internal Displacement Monitoring Centre (2018), 30.6 million new internal displacements associated with conflict and disasters were recorded in 2017 across 143 countries and territories. The report says that most conflict displacement took place in Sub-Saharan Africa and the Middle East. The United Nations High Commission for Refugees (2016) says that 2.5 million people were displaced in Nigeria in 2016 alone. In Benue State, total of 80,000 IDPS were registered as at January, 2018 in four camps spread Daudu, Tse-Ginde, Gbajimba all in Guma and Ugba in Logo local councils areas of Benue State (Premium Times, 2018).

The status of an IDP increases one's risk of contracting HIV and AIDs as a result of the tendency for sexual exploitation from people who offer financial assistance. Scholars (Lam, McCarthy, Brennan, Vaccine, 2015; Guerrier, Zounoun, Delarosa, Defourny, Lacharite, Brown et al, 2009; Olwedo, Mworozi, Bachou, Orach, 2008) are in consensus that internal displacement has substantial effects on public health and the well being of the affected populations. This is largely because many risk factors work together to make IDPS vulnerable. This includes movement of mass populations and resettlement in temporary locations, overcrowding, economic and environmental degradation, poverty, inadequacy of safe water, poor sanitation and waste management. These conditions are further compounded by the absence of shelter, food shortages and poor access to healthcare (Connolly, Gayer, Ryan, Salama, Spiegel \& Heymann, 2004).

The peculiar situation of IDPs makes communicating HIV and AIDs services to them challenging. Nonetheless, communication remains cardinal for reaching IDPs. Communication is essential for healthcare access and utilization. No matter how interesting, useful and accessible healthcare services may be, if poorly communicated, or not even communicated to the target receivers, the objectives of such healthcare services may not be achieved. Such communication could take place through different media like radio, TV, newspaper, magazines, the new media, face-to-face, film, among others. This assumption is supported by evidence in literature as scholars (e.g., Wakefield, Loken, \& Hornik, 2010; Grilli, Ramsay, Minozzi, 2002; Agha, Van Rossem, 2002; Shefner-Rogers, Sood, 2010; Rahman, Islam, Rahman,2010; Singh, Rai, Alagarajan, Singh, 2012) who have attempted to establish the relationship between communication, through a variety of communication channels, and health care reported significant relationship between both variables. The place of communication in healthcare services could be examined from two broad perspectives. First, from the perspective of healthcare services providers to patients and second from healthcare services providers to the general public or a target segment of the society.

When health communication is between healthcare services providers to patients, it is largely reactive and treatment-focused. Whereas when health communication about health care services is targeted to the general public or a particular segment of the society, it is usually preventive. Suffice it to say that communication is essential for communicating HIV/ AIDS services to IDPs, it follows logically that understanding their information seeking behaviour is useful for effective HIVIAIDS programmes and information seeking behaviour. Johnson, (1997) says that health information seeking behaviour is the purposive acquisition of information from selected information carriers. The definition of Johnson is essential to the current study because information seeking behaviour is regarded as purpose driven. People seek for information to achieve certain objectives.

One of the theoretical framework that has been found useful for studies on information seeking behaviour is the uses and gratification propound in 1974 by Blumler and Katz to explain the motivation for media use. Okoro and Gever (2018) applied the theory the theory to examine gender differentials in mobile phone use pattern and the outcome showed that theory is useful for studying information seeking behaviour Therefore, this study applied the uses and gratification theory to examine the information seeking behaviour of IDPs in Benue State.

Information seeking behaviour and perceived source of credibility

Information seeking behaviour is an important aspect of communication research because it could provide better perspectives on how to communicate information to a target audience. As a psychological process, information seeking behaviour plays a fundamental role in predicting the communication engagements of people. Karunarathna, (2008) says that information seeking behaviour involves the searching, locating, retrieving and using of information. One important consideration in examining information seeking behaviour is source of credibility. Within the context of media studies, source of credibility describes perceived reliability of a communication source. Berlo, Lemert, and Mertz (1969) opine that credibility source 
construct includes three dimensions in interpersonal communication. These are: safety, qualification, and dynamism. Safety explains the general personality traits as perceived by listeners. Qualification describes the competence of the source while dynamism describes the degree to which a message recipient "admires and identifies with the source's attractiveness, power or forcefulness, and energy" (Larson, 1992: 226). Hovland, Janis and Kelly (1953), reported trustworthiness and expertise as two dimensions of credibility source. Trustworthiness describes the extent people have confidence in the source, expertise focuses on the ability of the source to deliver a particular message. Ugwu (2019) found that perceived source of credibility significantly correlates perception regarding information to conflict. Rainie, Fox, and Fallows, (2003) reported that the Internet was judged as a more believable medium by a considerable margin when users were asked to compare traditional news sources with their online counterparts, such as CNN with CNN.com The relevance of the result of Rainie et al is that the new media era has also challenged the credibility of other sources of information.

Theoretical Framework and Hypotheses Development

This study found expression on Uses and Gratification theory (U\&G). Blumler and Katz propounded the theory in 1974 to explain the motivation for media use. However, the theory has been found useful for studying media use pattern. Campbell and Kwak (2011) argue that even though most applications of Uses and Gratification pinpoint the ways in which motivations determine media use behaviour, the framework also posits that usage patterns play an essential role in shaping social outcomes. Luo (2002) says that $U \& G$ theory assumes that people are actively involved in media usage and interact highly with the communication media by building profile groupings of related uses and theoretically associated gratifications. Finn (1997: 508-509) notes that the "most critical" components of U\&G theory are "(a) the social and psychological origins of audience needs, (b) the different patterns of media exposure that purportedly result, and (c) the differential engagement in other activities". Based on U\&G theory, the researchers formulated the following hypotheses

H1: There is a significant relationship between information seeking behaviour and sources of information.

H2: There is a significant relationship between information seeking behaviour and motivation for information seeking behaviour

H3: Perceived HIVIAIDS information need is significantly associated with information seeking behaviour of IDPs.

H4: Knowledge of HIVIAIDs status of IDPs is associated with information seeking behaviour.

H5: Information seeking behaviour is associated with level of attention to source credibility.

\section{Materials and Methods}

Survey research design was used for this study. The study was conducted in Benue State. The state was chosen for this study because it has one of the highest numbers of HIVIAIDs patients in Nigeria. Benue State also has many IDPs as a result of the herdsmen-famers conflict. The population of this study was made of 80,000 registered IDPs from four camps in Benue State namely Daudu, Tse-Ginde, Gbajimba all in Guma and Ugba in Logo local councils' areas of Benue State (Premium Times, 2018). The sample size for this study was made up of 384 IDPs. The Cochran formula was used to derive the sample size. A total of 96 IDPs were sampled from each of the four camps. The researcher used a self-developed questionnaire to collect data for the study. A researcher engaged three research assistants who were camp officials to help in the administration of the instrument.

\section{Measures}

The following measurement indices were used in this study.

\section{Sources of information and motivation}

The respondents were requested to provide the sources through which they receive information and also indicate the motivation for doing so.

Information seeking Behaviour:

Information seeking behaviour was classified into low information seeking behaviour and high information seeking behaviour. The indices for high and low information seeking behaviour are presented in the following table:

Table 1: Information seeking behaviour measures

\begin{tabular}{lll}
\hline S/N & High Information seeking behaviour & Low information seeking behaviour \\
\hline 1 & Frequent information seeking behaviour & Less frequent information seeking behaviour \\
2 & Longer duration in information seeking efforts & shorter duration in information seeking efforts \\
3 & $\begin{array}{l}\text { Contacting multiple sources in information seeking } \\
\text { behaviour }\end{array}$ & $\begin{array}{l}\text { Contacting few sources in information seeking } \\
\text { behaviour }\end{array}$ \\
4 & Making extra-efforts to verify information sought. & Making less efforts to verify information sought. \\
\hline
\end{tabular}

The respondents were requested to indicate their information seeking behaviour using the above indices.

\section{Attention to the source of credibility}

Dichotomous response format of 'yes' and 'no' was used to assess the source of credibility. The two dimensions of Hovland, et al (1953) were used. They are trustworthiness and expertise. Therefore, the researchers asked the respondents to ascertain if they pay attention to source of trustworthiness and expertise in their information seeking behaviour.

\section{Knowledge of HIVIAIDs Status}

Here, the respondents were asked to report if they were aware of their HIVIAIDs status or not. We did not ask them to tell us their actual status because of the sensitivity of the matter.

Data Analysis

In the analysis of data for this study, the researcher used both descriptive and inferential statistics. Among the descriptive statistics, simple percentages were used while among the inferential statistics, chi-square test of independence was used. The hypotheses were tested at 0.05 level of significance.

Results

A total of 384 copies of the questionnaire were administered to the respondents. Out of this number, 347 representing $90 \%$ were filled and returned. The remaining 37 were either wrongly filled or not returned.

\section{Demographics}

The demographics of the respondents showed that the sample was $67 \%(232)$ male and $33 \%$ (115) female. Also, the mean age of the respondents was 44 (ranged 20 to 67 years). The IDPs were largely famers and mostly illiterate. Their main religion is Christianity as Benue is largely a Christian state. 
Table 2: Sources of Information and sources of information

\begin{tabular}{lcccc}
\hline \multicolumn{1}{c}{ Grouping } & $\mathbf{X}^{\text {2cal }}$ & df & $\begin{array}{c}\text { Critical } \\
\text { value }\end{array}$ & Decision \\
\hline $\begin{array}{l}\text { information } \\
\text { seeking behaviour }\end{array}$ & 133.917 & 2 & 3.841 & Sig \\
$\begin{array}{l}\text { Sources of } \\
\text { information }\end{array}$ & & & & \\
\hline
\end{tabular}

The essence of the table above was to ascertain the relationship between sources information seeking behaviour and sources of information. We found that respondents with high information seeking behaviour often seek information from multiple sources such as family members and friends, traditional media like media radio, TV and newspaper. It was also found that respondents with low information seeking behaviour often seek information from one source.

Table 3: Motivation for information

\begin{tabular}{lcccc}
\hline \multicolumn{1}{c}{ Grouping } & $\mathbf{X}^{\text {2cal }}$ & Df & $\begin{array}{c}\text { Critical } \\
\text { value }\end{array}$ & Decision \\
\hline $\begin{array}{l}\text { information } \\
\text { seeking behaviour } \\
\text { Motivation }\end{array}$ & 89.748 & 2 & 3.841 & Sig \\
\hline
\end{tabular}

In the table above, the researchers sought to ascertain if motivation for information influences information seeking behaviour. It was found that respondents who are motivated to seek information to meet specific need reported higher information seeking behaviour than their counterparts who have no specific need to meet. That is to say that those with problem to solve have higher information seeking behaviour than those who think they do not have problems to address.

Table 4: Perceived HIVIAIDS information need and information seeking behavior

\begin{tabular}{lcccc}
\hline \multicolumn{1}{c}{ Grouping } & $\mathbf{X}^{\text {2cal }}$ & Df & $\begin{array}{c}\text { Critical } \\
\text { value }\end{array}$ & Decision \\
\hline $\begin{array}{l}\text { information } \\
\text { seeking behaviour } \\
\text { Perceived need }\end{array}$ & 24.953 & 1 & 3.841 & Sig \\
\hline
\end{tabular}

In the table above, the researchers sought to ascertain the association between perceived need for HIV/ AIDs information need and information seeking behaviour of the respondents studied. It was found that respondents who reported higher need for HIVIAIDs information reported higher need for HIVIAIDs information than their counterparts who reported lower need for information on HIV/ AIDs. This means that when respondents feel that they need information about HIVIAIDs, they are likely to take deliberate steps to get such information than when they feel they have no need for such information.

Table 5: Knowledge of HIVIAIDs Status and information seeking behavior

\begin{tabular}{lcccc}
\hline \multicolumn{1}{c}{ Grouping } & $\mathbf{X}^{2 \text { cal }}$ & Df & $\begin{array}{c}\text { Critical } \\
\text { value }\end{array}$ & Decision \\
\hline $\begin{array}{l}\text { information } \\
\text { seeking behaviour } \\
\text { Knowledge of } \\
\text { HIVIAIDs }\end{array}$ & 58.268 & 1 & 3.841 & Sig \\
\hline
\end{tabular}

In the table above, the researcher sought to ascertain if knowledge of HIVIAIDs status influences the information seeking status of the respondents. It was found that res- pondents who have knowledge of their HIVIAIDs status are likely to report higher higher information seeking behaviour about HIVIAIDs than their counterparts who do not have knowledge of their HIVIAIDs status.

Table 6: Information seeking behaviour and level of attention to source credibility

\begin{tabular}{lcccc}
\hline \multicolumn{1}{c}{ Grouping } & $\mathbf{X}^{\text {2cal }}$ & Df & $\begin{array}{c}\text { Critical } \\
\text { value }\end{array}$ & Decision \\
\hline $\begin{array}{l}\text { information seeking } \\
\text { behavior } \\
\text { level of attention to }\end{array}$ & 33.635 & 1 & 3.841 & Sig \\
source of credibility. & & & & \\
\hline
\end{tabular}

In the table above, we examined if information seeking behaviour influences attention to source of credibility. The result of the current study showed that respondents who reported higher information seeking behaviour also pay attention to source of credibility than those who do not.

\section{Test of Hypotheses}

A total of five hypotheses were tested in this study. The result of the first hypothesis showed p-value of 0.001 ChiSquare value of 133.917 at $2 \mathrm{df}$. This suggests a significant relationship between information seeking behaviour and sources of information of information among IDPs. The result of the second hypothesis a p-value of 0.001 with Chi-square value of 89.748 at $2 \mathrm{df}$. Therefore, the result showed that there exists significant relationship between information seeking behaviour and motivation for seeking the source of information. The third hypothesis sought to ascertain the relationship between perceived HIVIAIDS information need information seeking behaviour of IDPs. The result of the study showed significant relationship between both variables. This is because $P$-value $(<0.05$, $X^{2}=24.953$ at $1 \mathrm{df}$ ). Therefore, the researcher concludes that perceived HIVIAIDS information need is associated with information seeking behaviour of IDPs. The result of the fourth hypothesis sought to ascertain the association between Knowledge of HIVIAIDs status of IDPs and information seeking behaviour. The calculation yielded $p$ value $\left(p<.05, X^{2}=58.268\right.$ at $\left.1 \mathrm{df}\right)$. Therefore, the researcher concludes that there is a significant association between Knowledge of HIVIAIDs status of IDPs and information seeking behaviour. The result of the last hypothesis testing also showed significant association between information seeking behaviour and level of attention to source credibility $\left(p<0.05, X^{2}=33.635\right.$ at $\left.1 \mathrm{df}\right)$.

\section{Discussion of Findings}

This study examines the perceived HIVIAIDs information need and information seeking behaviour of IDPs in Benue State. The result of the study showed that friends and families were the main sources of information among IDPs in Benue State. This study has expanded that of Sambo (2017) who studied IDPs in Borno, Nigeria and only paid attention to their information needs without focusing on their sources of information. There was a significant relation relationship between information seeking behaviour and the sources of information among IDPs as the result showed that respondents who reported high information behaviour seek information from friends including radio while those who reported low information seeking behaviour seek information from family members. The source of information is very important because it could influence the manner people respond to messages received. This assumption is supported by a recent study of Ugwu (2019). It was also found that information seeking behaviour significantly influences the motivation for information seeking behaviour as most respondents who reported low information seeking behaviour are motivated 
to seek information on attacks on other communities while low information seeking behaviour respondents are motivated to seek information on donations to IDPs. This result is similar to that of Sambo (2017). The result equally revealed that perceived HIV/AIDs information needs are associated with information seeking behaviour. Knowledge of HIV/AIDs status was found to also be associated with information seeking behaviour.

Respondents who reported high information seeking behaviour are more likely to be critical of source of credibility than those who reported low information seeking behaviour. Overall, very few respondents reported having knowledge of their HIV/Aids status. This aspect of the result is similar to that of Harris and Cochrane (2009) who reported that low knowledge of HIV/Aids among IDPs in Uganda. This result has two implications. First, it has implications on the uses and gratification theory and secondly, it has implications on communicating HIVIAIDs information to IDPs in Benue State.

This result has implications on communicating HIV/ AIDs information to IDPs. First, to effectively communicate HIVIAIDs information to IDPs, opinion leaders should be engaged and trained bearing in mind that most of the IDPs get information from family and friends. This result also has implications on the welfare of Nigerian children because when people become HIVIAIDs positive, the children suffer most because they are at the risk of contracting it from their parents. In the event that the parents die, the children are left into the hands of guardians who may not give them the desired proper upbringing.

Regarding the uses and gratification theory, this study has provided data for understanding the motivation for information seeking behaviour of IDPs. Such knowledge could also provide a blue print for understanding the media use behaviour of IDPs. Overall, the result of the study confirmed the postulations of uses and gratification theory, indicating IDPs have motivation for engaging information seeking behaviour and such drive them in the sources they contact for information as well as their level of information seeking behaviour. Finn (1997) notes that the social and psychological origins of audience needs play a role in uses and gratification hypothesis. That component of Finn's categorization was found useful because IDPs have psychological and social needs and such needs define their information seeking behaviour. Perhaps, they do not consider HIVIAIDs information as meeting any of their needs, hence the low interest in HIVIAIDs information.

\section{Conclusion/ Recommendations}

This study examined information seeking behaviour of IDPs in Benue state with a view to examining the implications on HIVIAIDs communication framework. Based on the result of this study, the researcher concludes that most of the IDPs get information from families and friends and that the motivation for such information from donations to IDPs and attacks to other communities. The researchers also conclude that there is general low interest in HIVIAids information among IDPs. The basic contribution of this study is that it has provided evidence for understanding how to best communicate HIVIAIDs services to IDPs. This understanding could be useful for development partners like United Nations Education Scientific and Cultural Organization (UNESCO), United Nation Children Emergency Fund (UNICEF), among others. Based on the result of this study, the researcher recommends that opinion leaders should be used in communicating HIVIAIDS information to IDPs, Also, information about HIVIAIDs aimed at reaching IDPs should find a way of incorporating donations to them so as to attract their attention. Finally, further studies should be expanded to include media framing of IDPs.

\section{REFERENCES}

Agha, Sohail, Van Rossem, Ronan (2002). Impact of mass media campaigns on intentions to use the female condom in Tanzania. International Prospective on Sexual and Reproductive Health, 28 (3): 151-8.

Berlo, D. K., Lemert, J. B., \& Mertz, R. J. (1969). Dimensions for evaluating the acceptability of message sources. Public Opinion Quarterly, 33(4): 563-576.

Blumler, J. G., \& Katz, E. (Eds.). (1974). The uses of mass communications: Current perspectives on gratifications research. Beverly Hills, CA: Sage.

Campbell, C. \& Kwak, N. (2011). Mobile communication and civil society: Linking patterns and places of use to engagement with others in public. Human Research Communication. 37: 207-222.

Connolly, M. A., Gayer, M., Ryan, M. J., Salama, P., Spiegel, P., \& Heymann, D. L. (2004). Communicable diseases in complex emergencies: Impact and challenges. Lancet. 364: 1974-83.

Dobransky, K., Hargittai, E. (2012). Inquiring minds acquiring wellness: uses of online and offline sources for health information. Health Communication. 27 (4): 331-343.

Finn, S. (1997). Origins of media exposure: Linking personality traits to TV, radio, print, and film use. Communication Research, 24: $507-529$.

Grilli, R., Ramsay, C., Minozzi, S. (2002). Mass media interventions: effects on health services utilisation. Cochrane Database System Review (1). Retrieved from: http://onlinelibrary.wiley.com/doi/10.1002/14651858.CD000389/abstract

Guerrier, G., Zounoun, M., Delarosa, O., Defourny, I., Lacharite, M., Brown, V., et al. (2009). Malnutrition and mortality patterns among internally displaced and non-displaced population living in a camp, a village or a town in Eastern Chad. PLoS One, 4: 8077.

Hallyburton, A., Evarts, L. A., (2014). Gender and online health information seeking: a five survey meta-analysis. Journal of Consumer Health Internet. 18 (2): 128e142.

Hanson, C., West, J., Thackeray, R., Michael, M., Barnes, D., et al. (2014). Understanding and predicting social media use among community health Center patients: A cross-sectional survey. Journal of Medical Internet Research. 16: e270.

Harris, C. \& Cochrane, L. (2009). Survey of HIV and AIDS knowledge in internally displaced persons camps in northern Uganda. International NGO Journal, 4 (5): 190-202.

Hovland, C., Janis, I., \& Kelley, J. (1953). Communication and persuasion. New Haven, CT: Yale University Press.

Internal Displacement Monitoring Centre (2018). Global Report on Internal Displacement. Retrieved from https://www.internaldisplacement.org/global-report/grid2018/downloads/2018-GRID.pdf

Julien, H. (1996). A content analysis of the recent needs and uses literature. Library and Information Science Research, 18: 53-65.

Johnson, D. J. (1997). Cancer related Information Seeking. Hampton Press, Cresskill, NJ.

Karunarathna, A. (2008). Information seeking behaviour of University Teachers in Sri Lanka in the field of management studies. Retrieved from http://eprints.rclis.org/handle/10760/12699.

Larson, C. U. (1992). Persuasion: Reception and responsibility (6th ed.). Belmont, CA: Wadsworth Publishing Company.

Lorence, D., Park, H., (2007). Gender and online health information: a partitioned technology assessment. Health Information. Library. Journal, 24 (3): 204-209.

Luo, X. (2002). Uses and gratifications theory and e-consumer behaviours: A structural equation modeling study. Journal of Interactive Advertising, 2(2). Retrieved from http://jiad.org/article22.html

Mooney, E. (2005). The Concept of Internal Displacement and the Case for Internally Displaced Persons as a Category of Concern. Refugee Survey Quarterly, 24, (3): 17-28. 
National Agency for the Control of AIDS (2017). Retrieved from https://www.avert.org/professionals/hiv-around-world/subsaharan-africa/nigeria

Okoro, N. \& Gever, V. C. (2018). Gender differentials in mobile phone communication pattern among youth: Evidence from a qualitative study. Nsukka Journal of Foreign languages and Library Studies, 1: 133-143.

Olwedo, M. A., Mworozi, E., Bachou, H., Orach, C. G. (2008). Factors associated with malnutrition among children in internally displaced person's camps, Northern Uganda. African Health Science, 8: 244-52.

Premium Times, (2018 January 10). Benue Killings: 80,000 internally displaced persons registered. Retrieved from https:// www.premiumtimesng.com/news/-headlines/255073-benuekillings-80000-internally-displaced-persons-registered.html

Rahman, M., Islam, R., \& Rahman, M. (2010). Antenatal care seeking behaviour among slum mothers: a study of Rajshani City Corporation, Bangladesh. Clinic Basic Research, 10: 50-56.

Sambo, S. (2017). Internal displaced persons and their information needs. Library Philosophy and Practice (e-journal). 1512. http://digitalcommons.unl.edu/libphilprac/1512

Shefner-Rogers, C., Sood, S. (2010). Involving husbands in safe motherhood: effects of the SUAMI SIAGA campaign in Indonesia. Journal of Community Health Nursing. 9(3): 233-258.

Singh, M. \& Singh, A. (2013). A study of media preferences and leisure time management of judges. Global Journal of Enterprise Information System, 12-17.
Singh, P. K., Rai, R. K., Alagarajan, M., \& Singh, L. (2012). Determinants of maternity care services utilization among married adolescents in rural India. PLoS One. 7(2): e31666. DOI: 10.1371/ journal.pone.0031666

Ugwu, A. (2019). Perceived source credibility and public perception of information on herdsmen /farmers conflict in Nigeria. International Journal of Communication: an interdisciplinary Journal of communication Studies, 23: 1-11.

United Nations Commission on Human Rights (1992). Analytical Report of the Secretary-General on Internally Displaced Persons, UN Doc. E/CN.4/1992/23 (14 February 1992), para. 17.

United Nations Commission on Human Rights, Report of the Representative of the Secretary-General on Internally Displaced Persons: Guiding Principles on Internal Displacement, UN doc. E/ CN.4/1998/53/Add.2 (11 February 1998).

United Nations High Commission for Refugees (2016). Global trends forced displacement in 2016. Retrieved from https:// www.unhcr.org/5943e8a34.pdf

United Nations Programme on HIV/AIDS (2017). UNAIDS, data. Retrieved from https://www.unaids.org/sites/default/files/ media_asset/20170720_Data_book_2017_en.pdf

Wakefield, M. A., Loken, B., \& Hornik, R. C. (2010). Use of mass media campaigns to change health behaviour. Lancet; 376(9748): 1261-1271. DOI: 10.1016/S0140-6736(10)60809-4.

Wilson, T. D. (2000). Human information behaviour. Information Science Research, 3 (2): 49-55.

Верлумун Селестин Гевер,

Університет Нігерії (м. Нсукка, штат Енугу, Нігерія)

e-mail: Encyclopeadia100@gmail.com, ORCID 0000-0003-0618-5352

Габріель Альхассан Отта,

Державний університет (м. Анігба, итат Когі, Нігерія)

ORCID 0000-0002-8958-9258

\section{ІНФОРМАЦІЙНИЙ ВИМІР ПРОБЛЕМИ ВІЛ / СНІДУ У СПІЛЬНОТІ ВНУТРІШНЬО ПЕРЕМІЩЕНИХ ОСІБ НІГЕРІЇ}

У цьому дослідженні було проаналізовано інформацію щодо поведінки внутрішньо переміщених осіб (ВПО) у штаті Бенуе з метою розуміння, як найкраще доносити до них послуги з профілактики та лікування ВІЛ / СНІД, а також просувати політику, яка могла б допомогти боротися з бідністю дітей. В чотирьох центрах ВПО у штаті Бенуе взяли вибірку 384 внутрішньо переміщених осіб. Показники, які були виміряні в цьому дослідженні, включали: джерела інформації, мотивацію до пошуку інформації, поведінку щодо пошуку інформації, достовірність джерел та наявність у респондентів знань про ВІЛ/СНІД. Для вимірювання джерел інформації респондентам було запропоновано перерахувати джерела (ресурси), через які вони отримують інформацію, а також вказати мотивацію для цього. Поведінка респондентів вибірки, які шукають інформацію, була узагальнена як поведінка респондентів, що шукають інформацію з низьким рівнем (вмістом) інформації, і поведінка респондентів, що шукають інформацію з високим рівнем (вмістом) інформації. Індекси високої і низької поведінки пошуку інформації були надані респондентам, які підтвердили, що вони шукають таку інформацію. Увага до достовірності джерела інформації вимірювалась за допомогою дихотомічного формату відповідей "так" i "ні". Два аспекти, які використовувались у вимірюванні, - надійність та досвід. Окрім того, дослідники попросили респондентів уточнити, чи звертають вони увагу на достовірність джерел та досвід їхньої поведінки. Щодо знань про статус ВІЛ/СНІДу, респондентам було запропоновано повідомити: знають вони про свій ВІЛ/СНІД статус чи ні. I попросили вказати їх фактичний стан через чутливість цього питання. При аналізі даних для цього дослідження використовувалась як описова, так і отримана шляхом виведення статистика. Серед описової статистики використовували прості відсотки, тоді як серед статистики, отриманої шляхом виведення, використовувались тест-квадрат на тест незалежності. Гіпотези перевірені на рівні значущості 0,05. Результат показав, що більшість ВПО отримують інформацію від родини та друзів. Було виявлено, що поведінка щодо пошуку інформації суттєво пов'язана з джерелами інформації та мотивацією пошуку інформації. Крім того, сприйнята інформація про ВІЛ/СНІД пов'язана з інформацією про поведінку. Статус ВІЛ/СНІДу також був пов'язаний 3 інформацією про поведінку. Нарешті, існує суттєвий взаємозв'язок між пошуком інформації і довірою до джерела. Досліджено вплив цих результатів на політику комунікації з ВІЛ / СНІД.

Ключові слова: спілкування; пошук інформації; ВІЛ / СНІД; ВПО.

(C) Verlumun Celestine Gever, Gabriel Alhassan Ottah

Надійшла до редакції: 13.01.2020

Прийнята до друку: 31.01.2020

СХІД № 1 (165) січень-лютий 2020 р. 